\title{
NATURE LAB - \\ A NEW LECTURE HALL FOR GEOGRAPHY?
}

DOI: https://doi.org/10.18509/AGB.2017.09

UDC:502:551.4]:37

\author{
Danko Simić ${ }^{1}$, Jörn Harfst ${ }^{1}$ \\ ${ }^{1}$ Department of Geography and Regional Science, University of Graz, Austria \\ Corresponding author: danko.simic@uni-graz.at
}

Submitted: January 2017, Accepted: March 2017, Published: August 2017

\begin{abstract}
This paper discusses nature labs as new lecture halls for Geography on the example of the nature lab Altenberg. Therefore, innovative and practice-oriented methods of applied teaching are illuminated on the example of the lab's co-learning approach and the geomorphological educational trail, as an instrument of environmental education. (section2). An evaluation of the nature lab's impacts on the communal development is provided in section 3 and factors of success for installing a nature lab are detected, by evaluating lessons learned from 2013 till today. Altogether, the paper on hand can help to understand the focal points for running a nature lab. It also shows how new teaching methods in Geography can be applied in an innovative and practice-oriented way.
\end{abstract}

Key words: nature lab, co-learning, applied teaching, environmental education, educational trail;

\section{Introduction}

The nature lab Altenberg (http://www.naturlabor-altenberg.com/) in Neuberg an der Mürz, Styria, Austria is located in the picturesque landscape of the Eastern Limestone Alps. This region - as other rural and peripheral regions in Europe is currently facing problems of demographic change. Since the end of the $19^{\text {th }}$ century breakdown of the regional ore-mining, which was the base of regional economy and development - the number of inhabitants is constantly decreasing [1]. Today the cadastral community has approximately 310 inhabitants, merely $10 \%$ are younger than the age of 15 [2].

One of the negative impacts of the selective exodus in Altenberg an der Rax was represented by the closing of the elementary school in 2012. Besides the local restaurants and shops, schools are one of the major social infrastructures in rural areas and pivotal places of social interactions [3]. Selective exodus and the shut-down of public infrastructure result in a reinforcing negative feedback loop, which can be described as social erosion. Social erosion denotes the process of transformation of a space due to the runoff of certain elements and following shrinking-processes that accelerate each other [4]. However, this abandoned site was detected as a potential for the communal development. By changing its image from a challenge to a chance, this vacant building was identified as an opportunity site for a second-hand space. Second-hand spaces use both tangible and intangible remains of the initial use to reintegrate an abandoned place in the lifecycle and foster its development. [5] The material remains are represented by the building itself and the existing infrastructure. Intangible remnants are harder to capture. In this specific case, it is the atmosphere of education and the ties to its former usage as an elementary school among the local population.

Considering the approach of second-hand spaces and utilizing the tangible and intangible assets of the former elementary school for a future development, the afterutilization should draw to the purpose of education. Together with numerous project 
partners this vacant area was transformed into the nature lab Altenberg in 2013 (Figure 1). (Partners are the municipality of Altenberg an der Rax today Neuberg an der Mürz, the University of Graz, the University of Natural Resources and Life Sciences Vienna, the University of Vienna, the
Technical University of Graz, the association "Landentwicklung Steiermark", the association "Herausforderung Wasser", the nature park "Mürzer Oberland" and many others, with subsidies by the province of Styria and the European Union.)

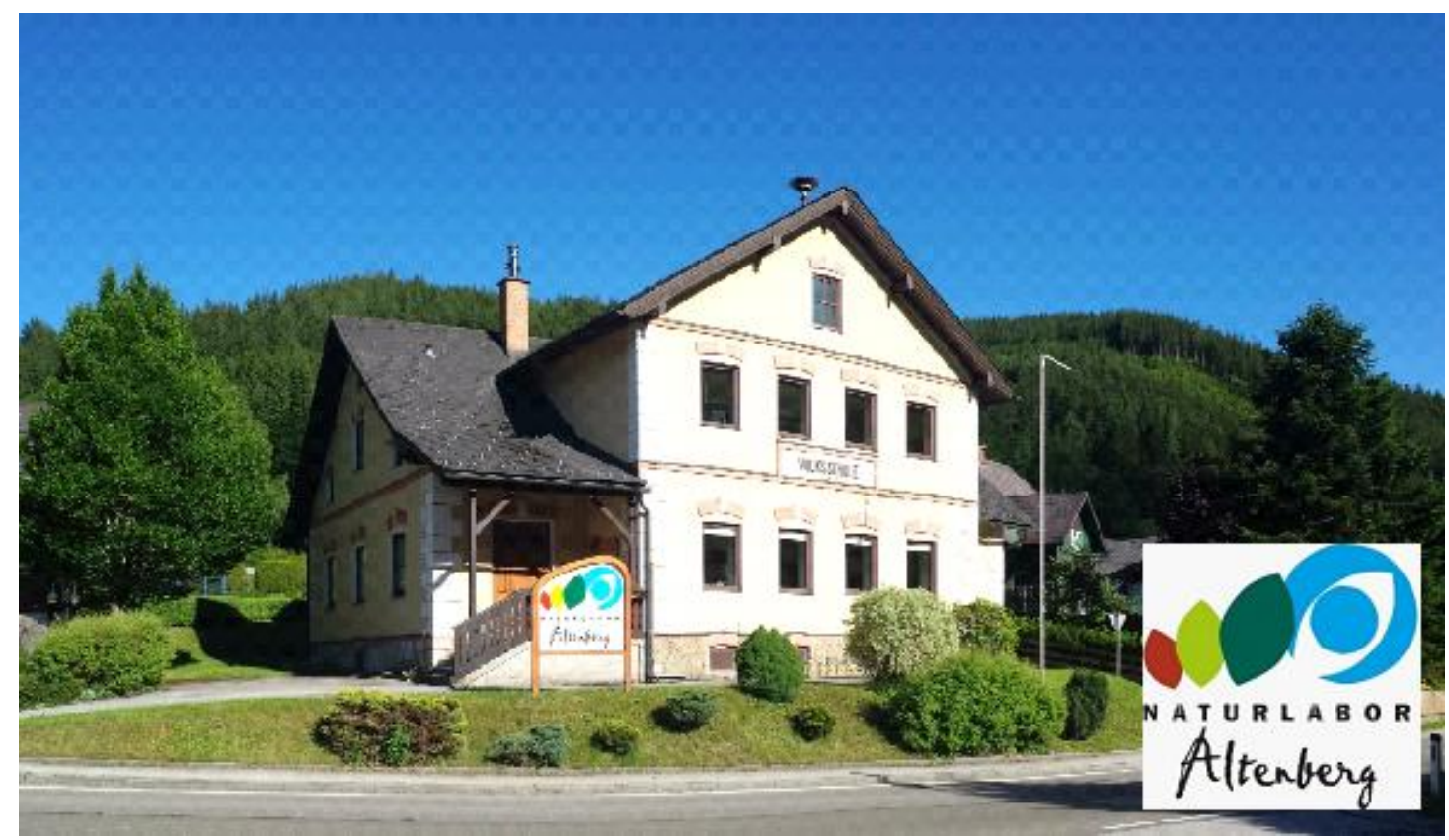

Figure 1. The nature lab Altenberg, picture: Danko Simić, 06.2016

The main organizational pillars of the nature lab are teaching and research, economy and tourism, communal and regional development and a platform for knowledge and experience exchange. All these layers are intertwining and go hand in hand with each other. They aim at fostering a positive communal development by attracting visitors and thereby spreading the idea of the nature lab outside of the region. [6]

\section{Teaching and research in the nature lab Altenberg}

The nature lab Altenberg is an innovative, practice-oriented competence-teaching and research center. The focuses are natural hazards in the Eastern alps and bordering regions and human-environment interactions, which enable an integrative geographical approach in both research and teaching. Thereby, education is not only limited to university students but also accessible to pupils, interested laymen, the local population and other visitors. [6] The nature lab does not make use of one-sided teaching systems but enables co-learning processes (Table 1). This multilayered approach brings external knowledge into the region and merges it with the local understanding and experiences of the population on site. The result is a comprehensive understanding of the region and new competences for all participating parties. 
Table 1. Co-learning and organizational relations within the nature lab Altenberg

\begin{tabular}{|c|c|c|c|c|}
\hline $\begin{array}{l}\text { Role within the } \\
\text { project }\end{array}$ & $\begin{array}{l}\text { Nature lab } \\
\text { Altenberg }\end{array}$ & Universities & Local population & $\begin{array}{l}\text { Municipality } \\
\text { Neuberg a.d. Mürz }\end{array}$ \\
\hline $\begin{array}{l}\text { Nature lab } \\
\text { Altenberg }\end{array}$ & $\begin{array}{l}\text { Medium between } \\
\text { the partners }\end{array}$ & $\begin{array}{l}\text { offers space and } \\
\text { infrastructure for } \\
\text { applied teaching, } \\
\text { fieldwork and } \\
\text { excursions }\end{array}$ & $\begin{array}{l}\text { offers space for } \\
\text { participation } \\
\text { processes, social } \\
\text { interaction, training } \\
\text { and helps to define } \\
\text { local identity }\end{array}$ & $\begin{array}{l}\text { brings positive } \\
\text { impulses for the } \\
\text { communal } \\
\text { development }\end{array}$ \\
\hline Universities & $\begin{array}{l}\text { provide knowledge } \\
\text { and experience, set } \\
\text { main framework, } \\
\text { use outcomes for } \\
\text { further research }\end{array}$ & Scientific partner & $\begin{array}{l}\text { include local } \\
\text { population in events } \\
\text { as local experts, } \\
\text { raise awareness for } \\
\text { related topics }\end{array}$ & $\begin{array}{l}\text { assist in } \\
\text { transformation } \\
\text { processes, give } \\
\text { advice and } \\
\text { guidance }\end{array}$ \\
\hline Local population & $\begin{array}{l}\text { inspirits the nature } \\
\text { lab by reintegrating } \\
\text { it into the everyday } \\
\text { life }\end{array}$ & $\begin{array}{l}\text { provides local } \\
\text { knowledge, } \\
\text { participates in } \\
\text { events }\end{array}$ & Local stakeholders & $\begin{array}{l}\text { fosters and steers } \\
\text { communal } \\
\text { development by } \\
\text { participation }\end{array}$ \\
\hline $\begin{array}{l}\text { Municipality } \\
\text { Neuberg an der } \\
\text { Mürz }\end{array}$ & $\begin{array}{l}\text { includes the nature } \\
\text { lab and its scientific } \\
\text { findings in } \\
\text { developmental } \\
\text { plans, sets main } \\
\text { framework }\end{array}$ & $\begin{array}{l}\text { cooperates closely, } \\
\text { assists in organizing } \\
\text { events }\end{array}$ & $\begin{array}{l}\text { encourages } \\
\text { inhabitants to } \\
\text { participate and } \\
\text { mediates between } \\
\text { population and the } \\
\text { Universities }\end{array}$ & Lead partner \\
\hline
\end{tabular}

Moreover, various benefits occur from the co-learning approach: The inhabitants of the municipality, for example, are affirmed to undertake a critical examination of the region, which can activate creativity and foster the communal development. Thereby, the regional identity is strengthened and the internal negative still-standing image is transformed to an image of a municipality with high level of participation and a vivid exchange and interactions in-between the inhabitants and the local decision makers. [7]

Students also profit. They get the possibility to apply their knowledge in the field. The knowledge transfer is divided into knowledge acquiring (mainly inputpresentations), analysis of the gathered information (mainly discussions and exercises) and practical implementation in the field with contextual and personal reflection in-between the steps. Practical implementation of knowledge is simulated in stakeholder and interest-conflict workshops. During these role-plays, the students slip into the role of a local stakeholder. Together in groups they work on tasks concerning different developmental issues. These tasks are closely connected to the region and draw to the real-life challenges.

As the sensitization for certain topics takes place in the realm of experience, absorbed information is processed on the factual and emotional level. Therefore, the level of consciousness is enhanced, which is consequently influencing future actions. [8]

The geomorphological educational trail which uses the same conceptual framework -is divided into eight stations and covers the topics: geological overview of the region, water, moraines, valley forms, karst hydrology, erosion and vegetation, ground moraines and anthropological morphology (Figure 2). Thereby, the stations are not installed in the landscape as usual: the educational boards are mobile, enabling the participants of the excursions and fieldwork to choose their own place of knowledge 
acquisition. With this approach the issue of furnished nature is avoided - i.e. numerous educational, prohibition and mandatory signs and boards which change the appearance of our environment and significantly contribute to its perception [8].
Moreover, this approach enables a simple opportunity to change topics, add new information or react to the personal demands of the visitors. However, there are suggested locations for the discussion of the boards' topics (Figure 2).

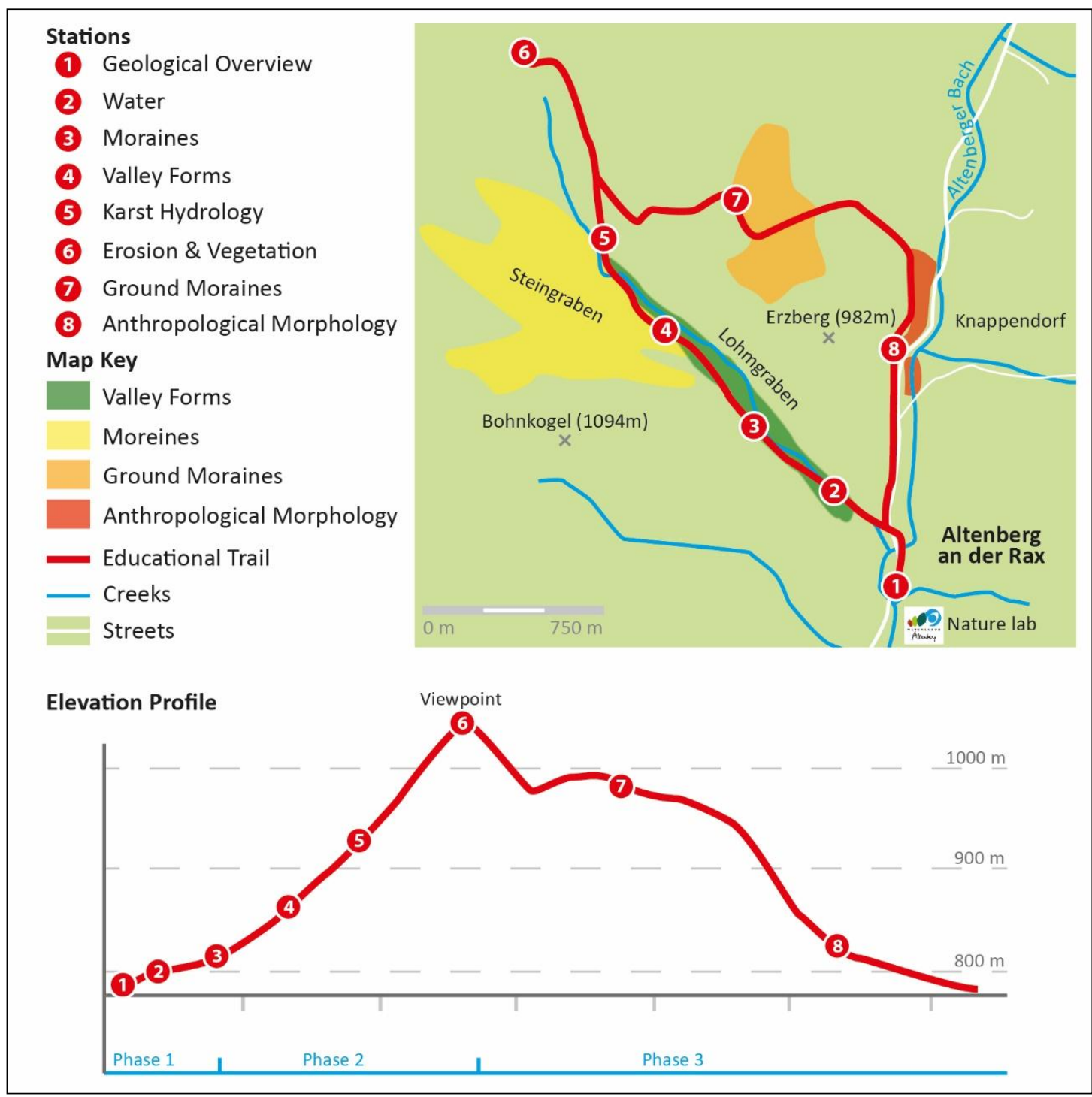

Figure 2. Geomorphological educational trail, Danko Simić, 2017

The educational trail in Altenberg is structured in three phases, which are prepared in an experience-based didactic way that follows scenic sequences. Phase 1 gives a general overview with a dense content and amount of educational boards in a comparable short distance. The hilly relief enables the visitor to move easily in the landscape and therefore is capable to capture more information. Phase 2 is characterized by a higher relief energy (approximately 200 $\mathrm{m})$. In this phase the distance between the stations are bigger to allow the participant of the excursion to reflect on the topics and rest in-between. The contents of the educational boards are more specific and condensed. The highest point of the educational trail offers a magnificent overview of the whole region. As mentioned above the emotional level is addressed especially in this point. The final phase is the decent and way back to the nature lab. The educational boards are distributed sparsely and the content is reduced to a minimum, securing that the visitor is not overloaded with new information. A hike along the geomorpho- 
logical nature trail is rounded down with a concluding discussion on the topics at the initial point of the trail. [9] Usually, the way is accompanied by a local, who enriches the educational offer with personal stories and experiences to bring the region closer to the visitor.

\section{Nature lab Altenberg - review and lessons learned}

There are various influences on the communal development by the nature lab Altenberg. As other factors are hard to capture and evaluate economic and accounting indicators - i.e. the overnight stays and organized events - are used to depict the positive influence of the nature lab in the last years.

Already in 2013 eleven university classes and excursions were held in the nature lab, bringing more than 350 students into the region. Moreover, five public events were organized with approximately 280 local and external participants with the topics: the main idea and aims of the nature lab, communal development, participation and natural hazards. These events were assisted by the scientific partners. [10]

The positive development continued in 2014: Even 1.200 overnight stays were recorded in the frame of 16 university classes and excursions organized by twelve different departments of the University of Graz, the University of Natural Resources and Life Sciences Vienna and the University of Vienna. In the same year, the training center for becks was installed, offering apprenticeship to understand becks as a system and their interaction with the settlement area with special respect to natural hazards. [10]

In 2015 the structural reform of Styrian municipalities - Gemeindestrukturreform 2015 - was implemented. Due to the idea of bigger administrative units, the former 542 (2010) municipalities were restructured to 287 new municipalities. The former selfdependent municipality of Altenberg an der Rax was unified with the three neighboring communes Kapellen, Mürzsteg and Neuberg an der Mürz. [11] This political event had a vast negative impact on the nature lab Altenberg. In this period, other topics were defined as main action fields. Consequently, the nature lab lost its importance and was not longer seen as a potential for communal development due to the remote location in the new municipality Neuberg an der Mürz.

Till 2016 the restructured municipality managed to overcome the challenges of the structural reform and again included the nature lab in its developmental agenda. The first tasks were to set a new framework for the restart. By reactivating former networks and partners the nature lab Altenberg should revive. An international summer school was organized in the nature lab bringing students and lecturers from nine different European countries into the region. Additionally, a geographic excursion was held. All in all, the nature lab had approximately 60 visitors (180 overnight stays) in the second half-year of 2016 showing a gradual recovery.

The negative events of 2015 depict how sensitive these small-scale projects react to external changes. Therefore, main success factors for running a nature lab were detected on the example of Altenberg. Comparable to the organizational pillars mentioned above, all factors are important and contribute their specific share to the overall output. Still there are some factors that can be described as more important: Self-recovery out of the region is the pivotal element for a successful and positive communal development. Pugalis and Gray state that the "[...] development potentialities (and constraints) are specific to the particular place [...], which highlights the need for approaches that are tailored to contextual conditions" [12]. This implies that there is no overall development model which is universally applicable. It is the specific set of elements - positive and negative - which influence the approaches in communal development. This place-based modality also considers soft skills. [12] Only with serious intentions and actions of the local stakeholders (local experts) and decision-makers, small-scale projects like the nature lab can exist and foster a future positive development.

Besides the local interest and active involvement, a strong network within the partners is indispensable. Close cooperation can be sustained by the entanglement of 
participating parties, e.g. a co-learning network. Within the network the nature lab is the intermediate medium bringing together all other project partners and offering space for knowledge and experience exchange.

In the first project concept the nature lab was strongly related to the building of the former elementary school [6]. The closing of the school in 2012 was the initial point for the conceptualization and implementtation of the nature lab as discussed above. However, the events in 2015 and their negative impact on the nature lab show that such projects should not be tied to a single location within a municipality but to the whole region. With a more scattered offer, such challenges and threats can be absorbed more easily.

\section{Conclusion}

The nature lab Altenberg sets an innovative framework for applied teaching and environmental education. It is especially the co-learning approach implemented in the region that needs to be highlighted. Bringing together different interest groups, educational backgrounds and disciplines, the nature lab offers multivariate possibilities of education and knowledge transfer. The pivotal approach is equal partners and participants within the project and no hierarchical structures with bottom-up or top-down approaches. Specially, Geography students can profit from these modalities as the nature lab focuses on applied teaching. In various lectures, excursions, fieldworks and workshops students can test their knowledge and work solution-orientated. Therefore, the nature lab and its surroundings can be denoted as a passable show-case for different geographical topics reaching from natural hazards to demographic change and selective exodus.

The nature lab initialized positive developments for the cadastral community Altenberg an der Rax and the municipality Neuberg an der Mürz. It attracts visitors from outside of the region, which has positive impacts on the regional tourism and economy. Moreover, the nature lab builds new self-confidence among the local population and fosters an emerging new identity. Gradually, the internal and external image of an unattractive abandoned region is transformed to a space of high local involvement and a "municipality of education and knowledge transfer".

Opposed to these positive developments there are several threats. These are mainly too little involvement and acceptance among the local population, stakeholders and decision-makers. By implementing strong project networks and incorporating all stakeholders equally these threats can be eliminated. With an innovative framework, a nature lab can foster the communal development and utilize endogenous assets to their full developmental extent.

\section{References}

[1] STATISTICS AUSTRIA. Registerzählung vom 31.10.2011, Austria, 2013, http://www.statistik.at/blickgem/rg1/g62104.pdf.

[2] STATISTICS STYRIA. Altenberg an der Rax - Soziodemografische Merkmale, Austria, 2014, http://www.statistik.steiermark.at/cms/dokumente/11680524_103033992 /d7ef3230/62104.pdf. (Own projection)

[3] Henkel, G. Der ländliche Raum. Gegenwart und Wandlungsprozesse seit dem 19. Jahrhundert in Deutschland: mit 15 Tabellen. 4. Auflage. Germany, pp 322-328, 2004.

[4] Giffinger R., Kramar H. Schrumpfung und Erosion im österreichischen Siedlungssystem: strukturelle Kennzeichen und regionale Perspektiven. In: Forum Raumplanung. Erosionsprozesse im Sieglungsgefüge Österreichs. Österreichische Gesellschaft für Raumplanung (eds.), Austria, 2008.

[5] Ziehl, M., Oßwald, S., Hasemann, O., Schnier, D. (eds.). Second Hand Spaces. Recycling sites undergoing urban transformation, Germany, pp 12-28, 2012. 
[6] Fischer, W. Projektkonzept Naturlabor Altenberg an der Rax im Naturpark Mürzer Oberland, Naturgefahrenforschung und Naturgefahrenmanagement, Austira, 2012, http://www.naturlabor-altenberg.com/images/Naturlabor/PraesentationskonzeptWien Stand09032012.pdf.

[7] Fischer, W. Das Naturlabor Altenberg an der Rax und seine nähere Umgebung, GeoGraz, Austria, vol. 55, pp 24-30.

[8] Ebers, S., Laux, L., Kochanek, H.-M. Vom Lehrpfad zum Erlebnispfad. Handbuch für Naturerlebnispfade. vol 1. Aufl. Wetzlar: NZH Verlag. Germany (1998)

[9] Eder, R., Arnberger, A., Brandenburg, C. Lehrpfade - Natur und Kultur auf dem Weg. Lehrpfade, Erlebnis- und Themenwege in Österreich. Böhlau vol. 18. Austria, Germany. 2007.

[10] Nature lab Altenberg. Internal evaluation of overnight stays and organized events in the period 2013 - 2015. Austria, 2015.

[11] Province of Styria. Die neue Steiermark. Land Steiermark - Amt der Steiermärlischen Landesregierung, http://www.gemeindestrukturreform.steiermark.at/, 2016.

[12] Pugalis, N., Gray, Nick. New Regional Development Paradigms: an exposition of place based modalities, Australasian Journal of Regional Studies, Australia, pp 181-203, 2016. 